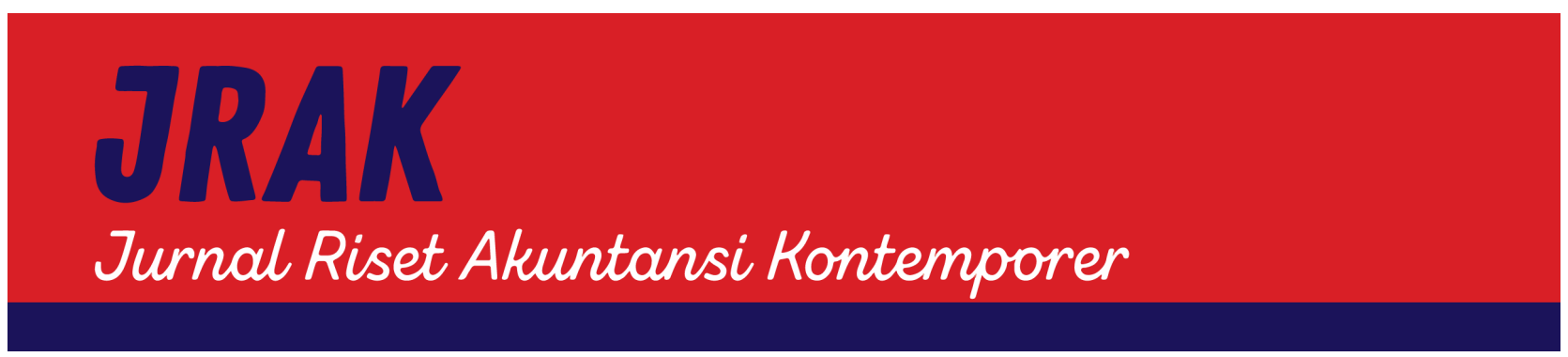

\title{
GENDER IN MOBILE WALLET ADOPTION BY USING UTAUT MODEL
}

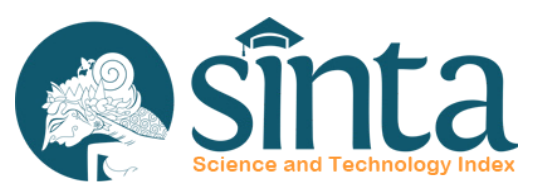

https://journal.unpas.ac.id/index.php/jrak/index

\author{
Hermaya Ompusunggu ${ }^{1} \bowtie$, Meilinda Dwi Anugrah ${ }^{2}$ \\ 1,2Universitas Putera Batam \\ $\checkmark$ hermaya@puterabatam.ac.id \\ J1.R.Soeprapto, Muka Kuning, Tembesi Kota Batam
}

\begin{tabular}{l} 
Article Info \\
\hline History of Article \\
Received: $17 / 12 / 2020$ \\
Revised: $4 / 3 / 2021$ \\
Published: $25 / 4 / 2021$ \\
\hline
\end{tabular}

Jurnal Riset Akuntansi Kontemporer

Volume 13, No. 1, April 2021, Page 26-31

ISSN 2088-5091 (Print)

ISSN 2597-6826 (Online)

Keywords: performance expectations; business expectations; social influence; facilitating conditions; gender; intention to use m-wallet

\begin{abstract}
Mobile wallets (m-wallets) have replaced physical wallets and also replaced the use of debit and credit cards. This study aims to analyze the effect of gender on m-wallet adoption by using the UTAUT model. The research used quantitative approach with primary data was done by distributing online questionnaires. The sample was using purposive sampling and obtained $290 \mathrm{~m}$-wallet users in Batam City who made a transaction through digital-based payment application during five months. The data analysis utilized SEM Partial Least Square. The results showed that performance and business expectations, social influence, and facility conditions had positive and significant effects on the intention to use m-wallets in Batam City, while gender did not have the effect in its relationship.
\end{abstract}

\section{INTRODUCTION}

Today's development of technology have transformed the traditional payment systems into digital payment systems. The level of use of digital application-based payment services depend on mobile devices since it is easier and more practical to carry out daily transactions. In addition, the existence of incentives provided to users attracts attention and triggers the use of m-wallets across all age groups (Nag, 2019). M-wallets or mobile wallets, known as mobile payments, are one of the most frequently used approaches for mobile payment services with internet support based on financial regulations (Qin. Z. Sun, 2017).

M-wallets have replaced physical wallets and also replaced the use of debit and credit cards which allow users to make online payments using mobile phones (Sharma, 2018). M-wallet supports various types of monetary transactions such as Consumer-to-Business (C2B), Consumer-to-Consumer (C2C), Consumer-toMachine (C2M), and Consumer to Online (C2O) (Shin, 2009). M-wallets are increasingly being adopted in advance and developing countries to increase the scale of productivity and excellence of banking services (Sharma, et al. 2018). M-wallet technology includes billing (direct billing), Quick Response (QR) and barcode, Near Field Communication (NFC), and cloud-based solutions (Leong, et al. 2020).

Like other advance countries, Indonesia also has m-wallet-based payment application services. The GO-PAY application is the m-wallet application most used by users, followed by PAYPAL and GRABPAY. However, the volume of m-wallet transactions as a payment service is not that high compared to transactions via ATM 
transfers, debit cards, and internet banking (Venture, 2018). When compared to other ASEAN regions, the growth of mobile payments in Indonesia is still left behind (Taufan \& Yuwono 2019). Indonesia only grew around $9 \%$, while Vietnam experienced the largest growth in the use of mobile payments at $24 \%$ (Global Consumer Insights Survey, 2019).

Several m-wallet payment applications in Indonesia are OVO, Dana, Link Aja, and Jenius, quoted from iPrice Group's research in collaboration with data analysis company App Annie, the digital-based payment application with the most users is occupied by GO-PAY, OVO, Dana and Link Aja (Devita, 2019). This digitalbased payment application can be used by all backgrounds through their mobile phones.

The use of m-wallets has not been well distributed across regions especially in the city of Batam. The use of the application is still limited in the Grab application in collaboration with OVO and Gojek by using GO-PAY. These two applications are the most widely used in Batam City. Other applications such as Dana, Link Aja, and Jenius are still relatively common for the Batam community. This indicates that not all people use $\mathrm{m}$-wallet payment applications.

This study aims to identify the factors that influence an individual's intention to use the m-wallet with the UTAUT (Unified Theory of Acceptance and Use of Technology) model. In addition, this study also analyzes the effect of gender as a moderating variable on the use of $\mathrm{m}$-wallets by individuals. This research contributes for the government programs to create the digital economy in various industrial sectors, particularly to provide solutions for cashless transactions in Indonesia. This research also contributes for service providers to provide information about the factors that influence users to use the m-wallet of each application service provider so that the application service provider can provide satisfaction for all users.

$\mathrm{M}$-wallets are referred to as mobile payments, which is an approach that is often used for payment services via smartphones using internet support (Qin, et al. 2017). M-wallet is part of m-commerce that allows users to make transactions, shop online, and share the services available. Users only need to use a mobile device with internet support if they want to make payment transactions (Keong, et al. 2012). There are four types of m-wallets, they are (Leong, et al. 2020): (1) semi-closed wallets (can be refilled, but there is no cash withdrawal or exchange. Users are only allowed to buy products from sellers who partnered with $\mathrm{m}$-wallet service providers; (2) semi-opened wallets (connected to a bank but users cannot make cash withdrawals); (3) open wallets (reloadable and can be connected to a bank. Users can make cash withdrawals through retailers or outlet agents); and (4) closed wallets (cannot be refilled with cash and no cash withdrawals). In general, $\mathrm{m}$-wallet security involves the following functions (Sharma, 2018): (1) creation of user identity and verification to check authenticity; (2) there are various options for conducting financial transactions, and (3) provisions for conducting m-commerce transactions, and there are security provisions.

Information technology will enchance performance if the technology can be accepted and used first by its users. There are several theories explaining how this technology is accepted and used by its users (J,2008). Previous research examines theories about technology acceptance by system users. These theories include: Theory of Reasoned Action (TRA), Technology Acceptance Model (TAM), Theory of Planned Behavior (TPB), and others. From these theories, Venkatesh, et al. (2012) proposed a unified theory of acceptance and use of technology (UTAUT) as an alternative to the TAM model (Keong, et al. 2012) and proposed four constructs that have a significant influence in determining user acceptance and user behavior, they are; performance expectancy, effort expectancy, social influence, and facilitating conditions. This study uses the UTAUT model to determine which variables have a significant influence on individual behavioral intentions in using $\mathrm{m}$-wallets through digital-based payment applications..

Performance expectancy is the extent to which each individual believes that using the system will improve their performance. There are five constructs in performance expectations, they are: extrinsic motivation, perceived usefulness, job-fit, and outcome expectations, relative advantage (Venkatesh, et al. 2012). Previous research had stated that performance expectations are the main antecedents of the adoption of digital-based payments. The main purpose of the adoption of digital-based payments is used for bill payments, online shopping, and entertainment (Sobti, 2019; Abrahão, et al. 2016). In addition, previous research also showed a positive relationship between performance expansion and the intention to use mobile payment technology. The $\mathrm{m}$-wallet system that is done through digital-based payments provides convenience and improves performance for consumers to carry out daily financial transactions (Gunawan, et al. 2019; Sivathanu, 2019). The first hypothesis is that performance expectations have a positive and significant effect on individual intentions to use $\mathrm{m}$-wallets through digital-based payment applications.

Expectancy effort is the level of ease of using a system. There are three constructs of business expectation, they are: perceived ease of use, complexity, and ease of use (Venkatesh, et al. 2012). Business expectations affect user satisfaction and continuity in using a system. If a system is easy to use, users will not be satisfied using the system and can stop using the system (Fruksa, 2013). If it does, then it becomes effortless, and vice 
versa, if a system turns out to be difficult to use, a high effort is required to use it (Jogiyanto, 2008). The result of previous research stated that business expectations have a positive effect on the intention to use online applications (Tak \& Panwar, 2017). In addition, business expectations can significantly drive the adoption of digital-based payment applications via mobile among the millennial generation. This is due to certain factors, such as convenience in using the application, fast, and easy to use (Gupta \& Arora, 2019; Baishya \& Samalia, 2020). The second hypothesis is that effort expectancy has a positive and significant effect on individual intentions to use $\mathrm{m}$-wallets through digital-based payment applications.

Social influence is the extent to individuals perceive interests that are believed by others which will influence them to use the new system. Social influence has an impact on individual behavior through three mechanisms, they are compliance, internalization, and identification (Venkatesh, et al. 2012). The previous research has shown that social influence is a strong supporting factor in explaining behavioral intention variances in accepting a digital-based payment system.

The willingness of individuals to use a system that influenced by the people's opinions around them (Junadi, 2015; Al-Okaily, et al. 2020). The third hypothesis is that social influence has a positive and significant effect on individual intentions to use $\mathrm{m}$-wallets through digital-based payment applications.

The facilitating conditions are defined as the extent to individuals believe that the organizational and technical infrastructure are available to support the use of the system (Venkatesh, et al. 2012). Previous researchers stated that the facilitating conditions had a positive effect on the use of online technology through mobile wallets. The use of m-wallets through digital-based payments has become widespread in electronic commerce and continues to grow in various regions (Chawla \& Joshi, 2019; Odoom \& Kosiba, 2020). The fourth hypothesis is that facilitating conditions have a positive and significant effect on individual intentions to use m-wallets through digital-based payment applications.

Gender is always associated with different perspectives on things. Men tend to be more critical and skeptical when knowing something, assessing, and confirming knowledge. While women are more dependent on an interaction and communication with other parties when studying an information technology. Venkatesh, et al. (2012) explained that women tend to be influenced by the opinions of others. Therefore, social influence on women is very strong in forming the intention to use a technology, meanwhile, men tend to be task-oriented. So that performance expectations in men are stronger in achieving a task. The fifth hypothesis is the relationship between performance expectations, business expectations, social influence on the intention to use m-wallets moderated by gender.

\section{METHOD}

The research method was done by using quantitative primary data was taken by distributing questionnaires online approximately one month via Google Docs. Purposive sampling technique used to determine the criteria for respondents. From 350 questionnaires were distributed using google form, about 290 were obtained that met the sample criteria, it was m-wallet users in Batam City who made a transaction through digital-based payment applications for the last five months (April 2020 to August 2020). The selection criteria for respondents was conducted because the number of $\mathrm{m}$-wallet users is still not well distributed in Batam City. Thus, the selection of these criteria can encourage more objective and targeted research results.

The research instrument was adapted from the previous research. Performance expectations, business expectations, social influence, facilitating conditions, and user interests were adapted from Venkatesh, et al. (2012), Anxiety and technology users' attitude were adapted from Rana, et al. (2017). Self-efficacy is adapted from Shaw (2014) and Venkatesh, et al. 2012). The research instrument used a Likert scale of five (strongly agree $=5$ to strongly disagree $=1$ ).

The testing of research instrument used the validity test and reliability test. The validity test used the Average Variance Extracted (AVE) value, if the AVE value is $>0.5$, then the research instrument is declared valid. While the reliability test was done using Cronbach's alpha value, if the alpha value was $>0.6$, then the instrument was declared reliable (Hair, et al. 2010). Researchers used SEM Partial Least Square (PLS) with WrapPLS 7.0 analysis as a statistical analysis method.

\section{RESULT}

This study has respondents who live in the city of Batam and its surroundings. The characteristics of respondents $r$ is dominated by women as much as $73 \%$, with an age range of 20-30 years as much as $65 \%$, part time students as much as 59\% with an income in the range of Rp. 4,000,000-Rp 5,000,000 about $46 \%$ (Tabel 1$)$. 
Based on the test results, the Tenenhaus GoF value is 0.746 and the ARS (Average R-Squared) value is 0.648 . This shows that the research model has met the goodness of fit, which is $64.8 \%$. Thus, the constructs of each research variable can be further tested by using the analysis of validity and reliability.

Furthermore, the test results showed that the research instrument is valid. This is indicated by the average variances extracted (AVE) value for each construct is $>0.5$ (Hair, et al. 2010). In addition, the research instrument was also declared reliable. Each research construct shows a composite reliability (CR) value of $>$ 0.8 and Cronbach's alpha $(\mathrm{CA})>0.7$ (Table 2).

After the instrument is valid and reliable, the next step is to test the hypothesis for each construct. Hypothesis testing used WrapPLS 7.0. The level of significance used in testing the hypothesis is 5\%. Based on the results of hypothesis testing, there are four supported hypotheses, while the other hypotheses are not. The results of the first hypothesis showed that performance expectations had a positive and significant effect on the intention to use $\mathrm{m}$-wallets through digital-based payment applications. Evidenced by the $\mathrm{p}$ value $=<0.001$ and the path coefficient (0.222) indicated a positive direction (Table 3).

Table 1. Respondent Demographic Data

\begin{tabular}{lcc}
\hline \multicolumn{1}{c}{ Category } & $\begin{array}{c}\text { Number of } \\
\text { Respondents }\end{array}$ & $\begin{array}{c}\text { Percentage } \\
(\%)\end{array}$ \\
\hline Gender & 77 & 27 \\
Male & 213 & 73 \\
Female & & \\
Age (year) & 69 & 24 \\
$\quad<20$ & 190 & 65 \\
20-30 & 19 & 7 \\
30-40 & 12 & 4 \\
$>40$ & & \\
Occupation & 97 & 33 \\
Private Employees & 5 & 2 \\
Government Employees & 172 & 59 \\
Student & 8 & 3 \\
Unemployment & 8 & 3 \\
Entrepreneur & & \\
Income (Rp) & 9 & 3 \\
$>10$ mil. & 58 & 20 \\
1-2 mil. & 73 & 25 \\
2-3 mil. & 133 & 46 \\
4-5 mil. & 12 & 4 \\
6-7 mil. & 3 & 1 \\
8-10 mil. & 2 & 1 \\
No Answer & & \\
\hline
\end{tabular}

Table 2. Validity and Reliability

\begin{tabular}{lccc}
\hline \multicolumn{1}{c}{ Construct } & AVE & CR & CA \\
\hline Peformance Expectations (PE) & 0.860 & 0.961 & 0.945 \\
Business Expectations (BE) & 0.859 & 0.961 & 0.945 \\
Social Influence (SI) & 0.743 & 0.919 & 0.878 \\
Facilitating Condition (FC) & 0.775 & 0.932 & 0.902 \\
Gender (GEN) & 1.000 & 1.000 & 1.000 \\
\hline
\end{tabular}

Table 3. Hypothesis Testing Results

\begin{tabular}{ccrcc}
\hline Hypothesis & Construct & P Value & $\begin{array}{c}\text { Path } \\
\text { Coefficient }\end{array}$ & Results \\
\hline 1 & $\mathrm{PE} \rightarrow \mathrm{NP}$ & $<0.001$ & 0.222 & Supported \\
2 & $\mathrm{BE} \rightarrow \mathrm{NP}$ & 0.031 & 0.108 & Supported \\
3 & $\mathrm{SI} \rightarrow \mathrm{NP}$ & $<0.001$ & 0.183 & Supported \\
4 & $\mathrm{FC} \rightarrow \mathrm{NP}$ & 0.041 & 0.101 & Supported \\
5 & GEN*PE & 0.217 & 0.046 & Unsupported \\
& GEN*BE & 0.262 & 0.037 & \\
& GEN*SI & 0.295 & 0.031 & \\
\hline
\end{tabular}

Source: Authors, 2020

\section{DISCUSSION}

The results of the first hypothesis supported the research results of Gunawan, et al. (2019) which stated that performance expectations has a positive effect on the interest in using m-wallet technology. In addition, performance expectations also affected interest in using digital payment systems (Sivathanu, 2019). Thus, the m-wallet system, which was taken through digital-based payments, provided convenience and improved performance for consumers to carry out daily financial transactions. The higher individual's performance expectations, the higher individual's intention to use m-wallets through digital-based payment applications.

The results of the second hypothesis showed that business expectations has a positive and significant effect on the intention to use the m-wallet, proven by the $\mathrm{p}$ value $=0.031$ and the path coefficient $(0.108)$ showed a positive direction. The easier it is to use technology, the higher the individual's intention to use the technology. The results of the second hypothesis supported the research results of Gupta \& Arora (2020); Khatimah \& Halim (2014); Baishya \& Samalia (2020), which stated that business expectations had a positive effect on the use of digital-based payments through cellular services. This shows that individuals have a high level of benefit when using m-wallets through digital-based payment applications. Digitalization provides convenience in transactions and can be accessed anywhere and anytime. Thus, the use of m-wallet is easy to use, so that the intention of individuals to use m-wallets through digital-based payment applications is also high. 
The results of the third hypothesis showed that social influence has a positive and significant effect on the intention to use the $\mathrm{m}$-wallet, proven by the $\mathrm{p}$ value $=<0.001$ and the path coefficient showed a positive direction. The higher the social influence encourages individuals to use technology, the higher the individual's intention to use it. The results of the third hypothesis support the research results of Junadi, (2015) and AlOkaily, et al. (2020). The conceptual social influence has two dimensions, they are subjective norms and peer influence. Social influence is a strong supporting factor in explaining the variance of behavioral intentions in accepting a digital-based payment system. The willingness of individuals to use a system is influenced by the opinions of the people around them. The results showed that individuals with high social influence have high intentions to use $\mathrm{m}$-wallets through digital-based payment applications.

The results of the fourth hypothesis indicated that the facilitating condition has a positive and significant effect on the intention to use the $\mathrm{m}$-wallet. This is proven by the $\mathrm{p}$ value $=0.041$ and the path coefficient showed a positive direction. The higher the facilities available, the higher the individual's intention to carry out a certain behavior. Thus, the use of m-wallets is supported through digital-based payment application facilities. Hasil pengujian hipotesis ke empat mendukung hasil penelitian Chawla \& Joshi (2019) yang menyatakan bahwa kondisi pemfasilitasi berpengaruh positif terhadap penggunaan teknologi online melalui dompet seluler. This shows that the facilitating conditions serve as structural guarantees to ensure payment security through digitization. In addition, Odoom \& Kosiba, (2020) shows that facilitating conditions also have a positive effect on the sustainable intention of micro companies to use digital payments via mobile. The use of $\mathrm{m}$-wallets through digital-based payments has become widespread in electronic commerce and continues to grow in various regions.

The results of the fifth hypothesis indicated that gender as a moderating variable does not have a significant effect on the intention to use the m-wallet. This indicates that there is no differences between both men and women in the acceptance of m-wallet technology. The results of the fifth hypothesis are in line with the results of previous studies which showed that gender moderation did not show significant results (Ye, et al. 2020); (Baishya \& Samalia, 2020). Gender differences were not found in the relationship between performance expectations, business expectations, and social influences on individual intentions to use m-wallets.

\section{CONCLUSIONS}

This study aims to analyze the effect of moderation on the intention to use m-wallets through digital-based payment applications using the UTAUT model. Researchers used the four constructs of the UTAUT model to analyze the strongest factors affecting individuals in using $\mathrm{m}$-wallets and the moderating effect of its constructs. The two proposed constructs have the highest level of significance in influencing the individual intentions to use m-wallets, especially in Batam City.

\section{REFERENCES}

Abrahão, R., Moriguchi, S. N. and Andrade, D. F. 2016. Intention of Adoption of Mobile Payment: An Analysis in The Light of The Unified Theory of Acceptance and Use of Technology (UTAUT). RAI Revista de Administração e Inovação, 13(3), pp.221-230.

Al-Okaily, M., Lutfi, A., Alsaad, A., Taamneh, A. and Alsyouf, A. 2020. The Determinants of Digital Payment Systems' Acceptance Under Cultural Orientation Differences: The Case of Uncertainty Avoidance. Technology in Society, 63, p.101367.

Amoako-Gyampah, K. 2007. Perceived Usefulness, User Involvement and Behavioral Intention: an Empirical Study of ERP Implementation. Computers in human behavior, 23(3), pp.1232-1248.

Au, Y. A. and Kauffman, R. J. 2008. The Economics of Mobile Payments: Understanding Stakeholder Issues for an Emerging Financial Technology Application. Electronic Commerce Research and Applications, 7(2), pp.141-164.

Baishya, K. and Samalia, H. V. 2020. Extending Unified Theory of Acceptance and Use of Technology with Perceived Monetary Value for Smartphone Adoption at The Bottom of The Pyramid. International Journal of Information Management, 51.

Balenkely, M. C. 1997. Womens ways of Knowing: The Development of Self. Voice and Mind, Basic Books.

Chawla, D. and Joshi, H. 2019. Consumer Attitude and Intention to Adopt Mobile Wallet in India-An Empirical Study. International Journal of Bank Marketing.

Devita.V. D. 2019. Siapa Aplikasi E-Wallet dengan Pengguna Terbanyak di Indonesia.

Fruksa, M. 2013. Mobile Technologies and Services Development Impact on Mobile Wallet Usage in Latvia. Procedia Computer Science, 26, 41-50. 
Global Consumer Insigth Survey. 2019. It's Time for a Consumer-Centred Metric Introduction, Return on Experience.

Gunawan, H., Sinaga, B. L. and Purnomo, S. P. 2019. Assessment of The Readiness of Micro, Small and Medium Enterprises in Using E-money Using The Unified Theory of Acceptance and Use of Technology (UTAUT) method. Procedia Computer Science, 161, pp.316-323.

Gupta, K. and Arora, N. 2019. Investigating Consumer Intention to Accept Mobile Payment Systems Through Unified Theory of Acceptance Model. South Asian Journal of Business Studies.

Hair, J.F., Celsi, M., Ortinau, D.J. and Bush, R.P., 2010. Essentials of Marketing Research (Vol. 2). New York, NY: McGraw-Hill/Irwin.

Jogiyanto, H. M. 2008. Sistem Informasi Keprilakuan. Yogyakarta: Andi.

Junadi, S. 2015. A Model of Factors Influencing Consumer's Intention to Use e-Payment System in Indonesia. Procedia Computer Science, 59, pp.214-220.

Keong, M. L. Ramayah, T., Kurnia, S. and Chiun, L.M., 2012. Explaining Intention to Use an Enterprise Resource Planning (ERP) System: an Extension of The UTAUT Model. Business Strategy Series. Emerald Insight, 13(4 pp), 173-180.

Khatimah, H. and Halim, F. 2014. Consumers' Intention to Use e-Money in Indonesia Based on Unified Theory of Acceptance and Use of Technology (UTAUT). American-Eurasian Journal of Sustainable Agriculture, 8(12), pp.34-40.

Leong, L. Y. Hew, T.S., Ooi, K.B. and Wei, J., 2020. Predicting Mobile Wallet Resistance: A Two-Staged Structural Equation Modeling-Artificial Neural Network Approach. International Journal of Information Management, 51, p.102047.

Nag, A. K. and Gilitwala, B., 2019. E-Wallet-Factors Affecting Its Intention to Use. International Journal of Recent Technology and Engineering (IJRTE), 8(4).

Odoom, R. and Kosiba, J. P. 2020. Mobile Money Usage and Continuance Intention Among Micro Enterprises in an Emerging Market - The Mediating Role of Agent Credibility. Journal of Systems and Information Technology.

Qin, Z., Sun, J., Wahaballa, A., Zheng, W., Xiong, H. and Qin, Z. 2017. A Secure and Privacy-Preserving Mobile Wallet with Outsourced Verification in Cloud Computing. Computer Standards \& Interfaces, 54, pp.55-60.

Ramadan, R. and Aita, J. 2018. A Model of Mobile Payment Usage Among Arab Consumers. International Journal of Bank Marketing.

Rana, N. P., Dwivedi, Y. K., Lal, B., Williams, M. D. and Clement, M. 2017. Citizens' Adoption of an Electronic Government System: Towards a Unified View. Information Systems Frontiers, 19(3), pp.549568.

Sharma, S. K., Mangla, S. K., Luthra, S. and Al-Salti, Z. 2018. Mobile Wallet Inhibitors: Developing a Comprehensive Theory Using an Integrated Model. Journal of Retailing and Consumer Services, 45, pp.52-63.

Shaw, N. 2014. The Mediating Influence of Trust in The Adoption of The Mobile Wallet. Journal of Retailing and Consumer Services, 21(4), pp.449-459.

Shin, D. H. 2009. Towards an Understanding of The Consumer Acceptance of Mobile Wallet. Computers in Human Behavior, 25(6), pp.1343-1354.

Sivathanu, B. 2019. Adoption of Digital Payment Systems in The Era of Demonetization in India: An Empirical Study. Journal of Science and Technology Policy Management.

Sobti, N. 2019. Impact of Demonetization on Diffusion of Mobile Payment Service in India: Antecedents of Behavioral Intention and Adoption Using Extended UTAUT Model. Journal of Advances in Management Research, 16(4), 472-497.

Tak, P. and Panwar, S. 2017. Using UTAUT 2 Model to Predict Mobile App Based Shopping: Evidences from India. Journal of Indian Business Research. 9(3), 248-264.

Taufan, A. and Yuwono, R. T. 2019. Analysis of Factors that Affect Intention to Use e-Wallet Through The Technology Acceptance Model Approach (Case Study: GO-PAY). International Journal of Science and Research (IJSR), 8(7), pp.413-419.

Venkatesh, V., Thong, J. Y. and Xu, X. 2012. Consumer Acceptance and Use of Information Technology: Extending The Unified Theory of Acceptance and Use of Technology. MIS Quarterly, pp.157-178.

Venture, M. 2018. Mobile Payment In Indonesia. Race to Big data Domination.

Ye, J., Zheng, J. and Yi, F. 2020. A Study on Users' Willingness to Accept Mobility as a Aervice Based on UTAUT Model. Technological Forecasting and Social Change, 157. 